$\begin{array}{ll}\text { Received } & : \text { 18 June } 2019 \\ \text { Revised } & : \text { 20 June } 2019 \\ \text { Accepted } & : \text { 28 June } 2019 \\ \text { Published } & : \text { 30 June } 2019\end{array}$

\title{
Transformation of Cultural Values in The Novel Di Bawah Langit yang Sama by Helga Rif (Literary Anthropology Approach)
}

\author{
Asep Ricky Subagya ${ }^{1, a)}$, Sri Suhita ${ }^{2)}$ \\ SMA Diponegoro 1 Jakarta, Jakarta, Indonesia \\ ${ }^{2}$ Program Studi Pendidikan Bahasa dan Sastra Indonesia, Fakultas Bahasa dan Seni, \\ Universitas Negeri Jakarta, Jakarta, Indonesia \\ E-mail: ${ }^{a)}$ rickysubagya56@gmail.com
}

\begin{abstract}
This study aims to obtain information about transformation of the cultural value in the novel titled Di Bawah Langit yang Sama by Helga Rif. This research use qualitative descriptive method based on anthropology of literature approach. This research was conducted from January to July 2019. In this study, there is a focus that is studied, which is the form transformation of cultural values, while the study's sub-focus includes (1) preservation cultural values and (2) revolution in cultural values. As for identifying and raising anthropological features in the novel using Koentjaraningrat theory which includes (1) human life equipment, (2) occupation, (3) social system, (4) language system, (5) arts, (6) knowledge system, and (7) religious system. In the novel entitled $D i$ Bawah Langit yang Sama had been found the elements of transformation of cultural values as much 103 data. Preservation of cultural values are 75 data, meanwhile the changes in the cultural values are 28 data. The most dominant data on maintaining cultural values is an element of human life equipment and social systems. Meanwhile, the most dominant data on changes in cultural value is an element of the social system. The results of this study have implications for 2013 Learning Curriculum 2013 Revision 2018 in grade XII, KD 3.8 interpret the author's view of life in novels that are read and $\mathrm{KD} 4.8$, which presents the results of interpretation of the views of the author either verbal or scripted.
\end{abstract}

Keywords: transformation of cultural values, Di Bawah Langit yang Sama, novel, literary anthropology

\begin{abstract}
Abstrak
Penelitian ini bertujuan untuk memperoleh informasi tentang transformasi nilai budaya dalam novel Di Bawah Langit yang Sama karangan Helga Rif. Penelitian ini
\end{abstract}


menggunakan metode deskriptif kualitatif dan menggunakan pendekatan antropologi sastra. Penelitian ini dilakukan sejak bulan Januari sampai dengan Juli 2019. Dalam penelitian ini terdapat fokus yang dikaji yaitu berupa transformasi nilai budaya, sedangkan subfokus kajian meliputi (1) pemertahanan nilai budaya dan (2) perubahan nilai budaya. Adapun untuk mengidentifikasi dan memunculkan ciri-ciri antropologis dalam novel menggunakan teori Koentjaraningrat yang meliputi (1) peralatan kehidupan manusia, (2) mata pencaharian, (3) sistem kemasyarakatan, (4) sistem bahasa, (5) kesenian, (6) sistem pengetahuan, dan (7) sistem religi. Dalam novel Di Bawah Langit yang Sama karangan Helga Rif ditemukan unsur transformasi nilai budaya sebanyak 103 data. Pemertahanan nilai budaya terwujud sebanyak 75 data, sedangkan perubahan nilai budaya sebanyak 28 data. Adapun data yang paling dominan pada pemertahanan nilai budaya ialah unsur peralatan kehidupan manusia dan sistem kemasyarakatan. Sementara itu, data paling dominan pada perubahan nilai budaya ialah unsur sistem kemasyarakatan. Hasil penelitian ini berimplikasi pada pembelajaran sastra Kurikulum 2013 Revisi 2018 di kelas XII, KD 3.8 yaitu menafsir pandangan pengarang terhadap kehidupan dalam novel yang dibaca dan KD 4.8 yaitu menyajikan hasil interpretasi terhadap pandangan pengarang baik secara lisan maupun tulis.

Kata kunci: transformasi nilai budaya, Di Bawah Langit yang Sama, novel, antropologi sastra

\section{PENDAHULUAN}

Sastra merupakan hasil karya manusia yang merupakan perwujudan dari hasil pemikiran ide, konsep, gagasan, ataupun imajinasi. Sastra diciptakan oleh seseorang guna memiliki tujuan untuk menyampaikan pesan melalui media secara komunikatif yang kemudian hasil dari penciptaan sastra disebut dengan karya sastra. Hal itu juga diungkapkan oleh Sumardjo dan Saini (1994) yang menyatakan bahwa sastra merupakan hasil ungkapan pribadi manusia secara mendalam, baik berupa pengalaman, pemikiran, perasaan, ide, semangat, dan keyakinan yang digambarkan dalam bentuk wujud konkret yang dapat membangkitkan pesona dengan bantuan alat atau media bahasa. Hal tersebut menunjukkan bahwa sastra dapat terwujud berdasarkan penggambaran manusia di dalam masyarakat melalui sebuah karya. Karya sastra dapat mengandung pikiran, pengalaman, ide, perasaan, semangat, kepercayaan (keyakinan), dan ekspresi pencipta yang diwujudkan dalam bentuk konkret serta bahasa.

Karya sastra memiliki banyak jenis, salah satunya adalah novel. Novel sendiri merupakan karya sastra berupa fiksi yang berbentuk prosa yang di dalamnya berisi cerita tentang kehidupan, baik melalui alur cerita maupun tokoh-tokoh yang ditampilkan dan biasanya diangkat dari peristiwa yang terjadi dalam kehidupan (Praptiwi, 2017). Novel memiliki fungsi sebagai kesenangan dan keindahan atau dulce et utile bagi pembacanya. Dengan membaca novel, seseorang dapat menciptakan efek rasa senang dalam jiwanya. Hal tersebut berasal dari jiwa seseorang setelah berimajinasi luas saat membaca novel. Selain itu, keindahan juga dapat diperoleh pembaca melalui kata-kata atau jalan cerita yang indah (Wellek \& Warren, 2014).

Pandangan batasan novel juga diungkapkan oleh Warsiman (2017) yang menyatakan bahwa novel merupakan prosa rekaan dan naratif dengan memiliki cerita yang panjang serta kompleks dengan menyuguhkan tokoh-tokoh yang dituangkan dalam serangkaian peristiwa dan latar secara tersusun yang saling berhubungan. Warsiman pun 
menambahkan bahwa struktur novel terdiri atas unsur-unsur naratif yang dibangun oleh aspek-aspek pendukung dalam atau internal cerita dalam novel yang saling mendukung satu sama lain dengan keseluruhannya. Adapun aspek pembangun dalam struktur novel terdiri atas tema, cerita, plot, tokoh dan penokohan, latar, sudut pandang pengarang, dan gaya serta nada cerita (Warsiman, 2017).

Adapula pendapat Suhita dan Purwahida (2018) yang menyatakan bahwa prosa fiksi dibangun oleh struktur yang terdiri atas unsur intrinsik dan ekstrinsik. Unsur intrinsik merupakan struktur dalam yang secara faktual dan nyata dapat dijumpai secara langsung pada saat membaca karya prosa fiksi. Adapun unsur instrinsik meliputi tema, amanat, alur, plot, latar, tokoh dan penokohan, watak dan perwatakan, bahasa, dan sudut pandang. Unsur tersebut dibangun secara bersama dan selaras guna menciptakan cerita yang padu. Sementara itu, unsur ekstrinsik ialah struktur yang berasal dari luar yang membangun prosa fiksi. Adapun unsur ekstrinsik mencakup faktor sosial, budaya, keagamaan, dan latar belakang pengarang.

Novel dibangun berdasarkan penggambaran tokoh-tokoh berdasarkan realitas sosial sehingga memiliki kekuatan dalam memberikan pengaruh psikologi kepada pembacanya (Amalia, 2018); Purwahida (2018). Novel tidak hanya memperhatikan bentuk, tetapi juga segi pesan atau makna yang ingin disampaikan kepada pembaca. Pengarang novel secara tidak langsung ingin menyampaikan pesan kepada pembaca melalui cerita dalam novelnya. Pesan tersebut biasanya berisi nilai-nilai yang disisipkan, baik secara tersirat maupun tersurat dalam sebuah novel. Nilai-nilai yang terkandung dalam novel seperti nilai moral, nilai agama, nilai sosial, dan nilai budaya. Salah satu nilai yang menarik untuk diteliti dalam novel adalah nilai budaya.

Maran (2000) mengatakan bahwa nilai berkaitan dengan menjelaskan apa yang seharusnya terjadi. Nilai memiliki cakupan yang luas, abstrak, standar kebenaran yang harus dimiliki, yang diinginkan, dan layak dihormati. Dengan demikian, nilai merupakan hal yang diakui secara luas oleh masyarakat, tetapi tak jarang nilai-nilai pun tidak ditaati oleh setiap anggota masyarakatnya. Namun, hal tersebutlah yang menentukan suasana dalam kehidupan kebudayaan dan masyarakat.

Nilai budaya dalam novel menggambarkan atau mencerminkan suatu budaya yang berlaku di dalam masyarakat secara nyata yang kemudian dituangkan ke dalam sebuah novel sehingga dapat dijadikan sebagai refleksi kehidupan. Novel tercipta sejalan atau selaras dengan konteks sosial yang merupakan bagian dari kebudayaan. Hal itu terjadi karena sastra dipengaruhi oleh masyarakatnya dan sekaligus dapat memengaruhi masyarakat. Selain itu, Wellek \& Warren (2014) dan Purwahida (2017) mengungkapkan bahwa sastra juga menyajikan kehidupan yang sebagian besar terdiri atas kenyataan sosial masyarakat. Karya sastra juga meniru apa yang ada di dunia dan alam subjektif manusia yang terdapat pada masyarakat. Sastra juga dapat disebut sebagai dokumen sosial atau sebagai potret kenyataan sosial dan kebudayaan.

Selain itu, Sudibyo, Sudargono, Sudiatmi, dan Triyanto (2013) juga menjelaskan fungsi nilai budaya dalam masyarakat yang menjadi pedoman tertinggi bagi tingkah laku manusia yang memiliki tingkatan paling abstrak. Adapun sistem-sistem tata kelakuan yang memiliki tingkatan lebih konkret dapat berwujud, seperti aturan khusus, norma-norma, semuanya berpedoman pada sistem budaya itu sendiri. Sistem nilai budaya sifatnya sangat kuat karena meresap dan tertanam pada jiwa masyarakatnya sehingga nilai budaya sukar diganti dengan waktu yang singkat.

Nilai budaya dalam sebuah novel dapat dikaji dengan pendekatan antropologi 
sastra. Antropologi sastra merupakan salah satu pendekatan sastra yang berguna untuk membantu menganalisis karya sastra berdasarkan aspek-aspek kebudayaan yang terkandung dalam karya sastra itu sendiri. Salah satu novel yang banyak mengandung nilai budaya ialah novel Di Bawah Langit yang Sama karangan Helga Rif. Novel tersebut menceritakan seorang gadis asal Bali bernama Anak Agung Ayu Indira. Ia bekerja di Singapura dan memiliki seorang kekasih asal negara tersebut. Bali dikenal memiliki adat istiadat yang sangat kental, dia ditentang oleh keluarga jika menikah dengan Maximilian. Namun, dengan tekad yang kuat dan bulat akhirnya ia dapat menikah dengan pria asal Singapura tersebut. Akan tetapi, dengan syarat Max harus masuk dan ikut ke dalam kasta keluarga Indira. Pada akhir cerita, Max dan Indira pun menikah dengan berbagai perbedaan budaya dan agama di antara keduanya. Hal tersebut merupakan salah satu kekayaan yang terdapat dalam novel, yaitu nilai budaya.

Guna menggali kekayaan nilai-nilai budaya lebih luas lagi yang terkandung dalam novel Di Bawah Langit yang Sama karangan Helga Rif, dibutuhkan pendekatan yang tepat yaitu antropologi sastra. Antropologi sastra merupakan ilmu subdisipliner antara ilmu antropologi dan sastra. Objek kajiannya yaitu perihal sastra dengan relevansi manusia (antropos). Antropologi sastra adalah kajian sastra yang menekankan pada budaya masa lalu. Antropologi yang menjadi kajian sastra adalah antropologi kultural yang mempelajari karya-karya yang dihasilkan manusia pada suatu kebudayaan seperti bahasa, mitos, sejarah, hukum, adat-istiadat, dan karya seni khususnya karya sastra. Hal tersebut senada dengan pendapat Ratna (2011) yang mengemukakan bahwa antropologi berarti mempelajari mengenai ilmu manusia, sedangkan sastra berarti alat untuk mengajar. Secara luas yang dimaksud dengan antropologi sastra adalah ilmu pengetahuan dalam hubungan ini karya sastra yang dianalisis dalam kaitannya dengan masalah-masalah antropologi. Dapat pula dikatakan bahwa antropologi sastra adalah analisis terhadap karya sastra yang di dalamnya mengandung unsur-unsur antropologi. Antropologi sastra digunakan untuk mengupas dan menggali perilaku budaya masyarakat yang terdapat dalam karya sastra.

Dengan demikian, untuk mengkaji nilai budaya dalam novel, diperlukan ilmu pengetahuan tentang kebudayaan agar dapat mengintrepretasi nilai yang terkandungnya dengan tepat. Adapun Koentjaraningrat (2015) menunjukkan adanya tujuh unsur kebudayaan universal atau dalam ilmu antropologi dikenal dengan istilah cultural universals, yang dapat digunakan untuk mengidentifikasi ciri-ciri antropologis untuk diteliti, yaitu: (1) bahasa, (2) sistem pengetahuan, (3) organisasi sosial, (4) sistem peralatan hidup dan teknologi, (5) sistem mata pencaharian hidup, (6) sistem religi, dan (7) kesenian.

Tujuan unsur kebudayaan tersebut menandakan bahwa memiliki sifat universal. Dengan demikian, unsur tersebut dapat ditemukan di dalam semua kebudayaan dari semua bangsa yang terdapat di dunia ini. Melalui tujuh unsur kebudayaan itu, dapat digali dan dicari nilai-nilai budaya yang terkandung di dalamnya sehingga dapat diinterpretasikan secara luas dan mendalam. Namun, dalam penelitian ini, susunan tujuh unsur nilai budaya diruntut sebagai berikut (1) peralatan kehidupan manusia, (2) mata pencaharian, (3) sistem kemasyarakatan, (4) sistem bahasa, (5) kesenian, (6) sistem pengetahuan, dan (7) sistem religi.

Setiap nilai pasti akan mengalami perubahan sesuai dengan perkembangan zaman atau bahkan tetap sesuai dengan peninggalan leluhurnya. Begitu pun dengan nilai budaya yang terdapat pada novel yang dihasilkan dari cerminan pada masyarakat, kemungkinan dapat terjadi perubahan, baik berupa penambahan, pengurangan, atau 
tetap yang dapat disebut dengan transformasi. Transformasi secara umum merupakan usaha yang dapat dilakukan untuk melestarikan budaya lokal dengan mengikuti perkembangan zaman agar tetap bertahan sehingga dapat dinikmati dan dirasakan oleh generasi selanjutnya. Selain itu, transformasi juga dapat dikatakan merupakan suatu perpindahan atau pergeseran dari suatu hal ke arah yang lain atau baru.

Hal tersebut senada dengan Pujileksono (2016) yang mengemukakan bahwa transformasi merupakan proses perpindahan atau pergeseran suatu hal ke hal yang lain atau bentuk baru tanpa mengubah struktur dan tatanan yang terkandung di dalamnya, meskipun dalam bentuknya yang baru telah mengalami perubahan. Saat transformasi maka terjadi perubahan dalam kerangka yang berisi struktur dan kultur. Perpindahan atau pergeseran tidak terjadi secara cepat dan total, tetapi secara bertahap dan perlahan.

Sementara itu, menurut Mardimin (1994) mendefinisikan transformasi budaya adalah perubahan konsep, bentuk, fungsi, dan sifat-sifat budaya untuk menyesuaikan dengan situasi dan kondisi perkembangan dunia. Perubahan budaya yang bersifat transformatif adalah perubahan yang direncanakan dan disengaja untuk tujuan tertentu. Namun, di samping itu terdapat pula pemertahanan budaya selama bertransformasi.

Begitu halnya dengan transformasi nilai budaya yang terdapat dalam novel $D i$ Bawah Langit yang Sama karangan Helga Rif terdapat pemertahanan atau pelestarian nilai budaya dan perubahan atau pergeseran nilai budaya yang dapat dianalisis dengan pendekatan antropologi sastra. Unsur pemertahanan atau pelestarian dan perubahan atau pergeseran nilai budaya sangat menarik untuk dikaji agar dapat memahami nilai budaya yang terdapat dalam novel tersebut. Dengan demikian, dapat diketahui nilai-nilai budaya yang terkandung sehingga dapat dilihat dan dikaitkan dengan cerminan budaya pada masyarakat.

Dipilihnya novel Di Bawah Langit yang Sama karangan Helga Rif sebagai bahan kajian dalam penelitian ini karena novel tersebut memiliki beberapa kelebihan. Pertama, novel Di Bawah Langit yang Sama karangan Helga Rif tidak mengandung unsur pornografi sehingga cocok digunakan sebagai pembelajaran sastra di sekolah, selain itu juga cocok sebagai bahan literasi siswa. Kedua, novel tersebut mengandung nilai-nilai budaya yang dapat dipetik hikmah dan kebermanfaatannya bagi pembaca guna meningkatkan rasa bangga atau nasionalisme yang tinggi terhadap budaya yang dimiliki Indonesia. Selain itu, terdapat pula beberapa alasan dipilihnya novel Di Bawah Langit yang Sama karangan Helga Rif sebagai bahan kajian penelitian ini, yaitu sebagai berikut.

Pertama, novel Di Bawah Langit yang Sama karangan Helga Rif mengangkat persoalan kehidupan yang berdasarkan cerminan dari kebudayaan masyarakat suku Bali yang menjadi inspirasi cerita dalam novel tersebut. Nilai-nilai budaya dapat digali dengan melihat tujuh unsur kebudayaan Bali yang terdapat dalam novel tersebut. Adapun tujuh unsur kebudayaan meliputi peralatan kehidupan manusia, mata pencaharian, sistem kemasyarakatan, sistem bahasa, kesenian, sistem pengetahuan, dan sistem religi. Setelah mengetahui nilai-nilai budaya tersebut, nilai-nilai itu kemudian menginterpretasikannya berdasarkan data yang diperoleh.

Kedua, dalam novel Di Bawah Langit yang Sama karangan Helga Rif terdapat transformasi nilai budaya berupa pemertahanan nilai budaya Bali yang diasumsikan dilakukan oleh tokoh utama ketika berada di Singapura, misalnya saat bekerja tetap melaksanakan ibadah dengan adat Bali. Lalu, ketika kembali ke Bali di tengah-tengah dunia modern saat ini, si tokoh masih tetap melaksanakan upacara Ngaben. Selain itu, juga ada pemertahanan pada sistem religi, sistem kemasyarakatan, dan sebagainya. 
Ketiga, pada novel Di Bawah Langit yang Sama karangan Helga Rif terdapat perubahan nilai budaya yang diasumsikan dilakukan pada tokoh utama terhadap adatistiadat Bali. Hal itu menunjukkan terjadinya perubahan pola pikir modern pada tokoh utama terhadap sistem kasta yang kental dalam pernikahan dan perekonomian, lalu perubahan sistem pengetahuan yang dilakukan tokoh utama wanita yang melanjutkan pendidikan ke tingkat yang lebih tinggi. Kemudian setelah lulus, dia memutuskan untuk bekerja dan pindah ke luar Bali yaitu ke Singapura yang pada mulanya tidak direstui oleh orang tuanya. Selanjutnya, terdapat perubahan sistem bahasa yang dilakukan tokoh utama dan beberapa tokoh yang ada yaitu penggunaan bahasa Inggris sebagai B3, setelah penguasaan bahasa Bali sebagai B1, dan bahasa Indonesia sebagai B2. Hal tersebut menarik untuk diteliti.

Antropologi sastra dipilih untuk memunculkan nilai-nilai budaya yang terdapat dalam novel tersebut. Nilai budaya yang terdapat dalam novel Di Bawah Langit yang Sama karangan Helga Rif akan dikaji dengan menggunakan teori kebudayaan Koentjaraningrat. Hal tersebut untuk memunculkan nilai-nilai budaya yang secara tersirat dan tersurat dituangkan oleh pengarang dalam novelnya. Untuk transformasi nilai budaya terdiri atas pemertahanan atau pelestarian yang kemudian dalam penelitian ini dipilih 'pemertahanan', serta perubahan atau pergeseran yang kemudian dalam penelitian ini dipilih 'perubahan'.

Tujuan penelitian ini adalah untuk mendeskripsikan transformasi nilai budaya yang meliputi (1) pemertahanan nilai budaya dan (2) perubahan nilai budaya yang terdapat dalam novel Di Bawah Langit yang Sama karangan Helga Rif. Kemudian mengaplikasikan hasil penelitian terhadap pembelajaran sastra di kelas XII berdasarkan Kurikulum 2013 Revisi 2018. Hal tersebut dapat diterapkan dalam KD 3.8 yaitu menafsir pandangan pengarang terhadap kehidupan dalam novel yang dibaca dan KD 4.8 yaitu menyajikan hasil interpretasi terhadap pandangan pengarang baik secara lisan maupun tulis.

\section{METODE PENELITIAN}

Penelitian ini merupakan penelitian deskriptif kualitatif terhadap suatu teks novel dengan kajian pustaka yang memiliki ruang lingkup kajian berupa novel Di Bawah Langit yang Sama karangan Helga Rif. Penelitian ini menggunakan pendekatan antropologi sastra sebagai pendekatan utama dalam analisis. Antropologi sastra merupakan adalah penelitian terhadap pengaruh timbal balik antara sastra dan kebudayaan (Endraswara, 2013). Selain itu, ruang lingkup penelitian juga berfokus pada transformasi nilai budaya yang terdapat dalam novel dengan subfokus yaitu (1) pemertahanan nilai budaya dan (2) perubahan nilai budaya yang terdapat dalam novel Di Bawah Langit yang Sama karangan Helga Rif. Prosedur penelitian merupakan serangkaian langkah dari awal hingga akhir guna menyelesaikan penelitian. Langkahlangkah tersebut terdiri atas tiga tahap, yaitu (1) tahap persiapan, yaitu menentukan topik atau jenis penelitian, mencari dan menemukan masalah, mencari landasan teori untuk menangani permasalahan tersebut, dan mengajukan proposal, (2) tahap pelaksanaan, yaitu mencari data primer ataupun sekunder, menyelesaikan data, dan menganalisis data, dan (3) tahap evaluasi, yaitu mengecek ulang hasil analisis, menarik simpulan, dan menyusun laporan (Endraswara, 2008).

Penelitian ini dilaksanakan dengan menganalisis isi karya sastra yang dibantu dengan tabel analisis data. Oleh karena itu, instrumen dalam penelitian ini adalah 
peneliti sendiri yang dibantu oleh tabel analisis data. Tabel analisis data memuat kutipan dari novel yang disusun berdasarkan subfokus (1) pemertahanan nilai budaya dan (2) perubahan nilai budaya yang terdapat dalam novel Di Bawah Langit yang Sama karangan Helga Rif. Adapun nilai-nilai budaya yang akan dianalisis meliputi tujuh unsur budaya, yaitu (1) peralatan kehidupan manusia,(2) mata pencaharian, (3) sistem kemasyarakatan, (4) sistem bahasa, (5) kesenian, (6) sistem pengetahuan, dan (7) sistem religi. Data yang dimasukkan ke dalam tabel klasifikasi hanya yang mengandung unsur subfokus tersebut sehingga penggunaan kutipan yang tidak diperlukan tidak dimasukkan ke dalam tabel.

\section{HASIL DAN PEMBAHASAN}

Data penelitian ini diambil dari novel berjudul Di Bawah Langit yang Sama karangan Helga Rif. Dalam novel Di Bawah Langit yang Sama karangan Helga Rif terdapat transformasi nilai budaya pada tujuh nilai budaya sebagai berikut.

\section{Peralatan Kehidupan Manusia}

Wujud pemertahanan nilai budaya pada peralatan kehidupan manusia terdapat dari segi makanan dan minuman, tempat tinggal, serta pakaian adat. Pemertahanan nilai budaya terdapat pada segi tempat tinggal yang dialami oleh tokoh Indira. Rumah keluarga Indira yang berada di Ubud, Bali, memiliki struktur bangunan yang menganut gaya rumah untuk golongan kasta Kesatria. Rumah tinggal di Bali dibedakan berdasarkan tingkatan-tingkatan kasta, status sosial, dan peranan pemiliknya di masyarakat. Pengelompokan tempat tinggal di Bali menjadi tempat tinggal utama, madya, dan sederhana. Hal tersebut dapat dilihat dari luas perkarangan, susunan ruang, tipe bangunan, fungsi, bentuk, dan bahan bangunan.

Adapun beberapa jenis tempat tinggal yang berada di Bali, meliputi: (1) geria yaitu rumah tinggal yang dimiliki orang yang berkasta Brahmana, (2) puri yaitu rumah tinggal untuk kasta Kesatria yang berperang penting pada masyarakat atau tokoh masyarakat, (3) jero yaitu rumah tinggal untuk kasta Kesatria yang tidak memegang peranan penting, (4) umah yaitu rumah tinggal dari kasta Waisya dan Sudra atau yang bukan dari kasta Brahmana atau Kesatria, dan (5) kubu yaitu tempat tinggal di luar pusat pemukiman, di ladang, di perkebunan, atau tempat-tempat kehidupan lainnya disebut Kubu atau Pekubon. Gaya bangunan tersebut hingga kini sebagian masyarakat masih mempertahankannya.

Pelataran halaman luar puri - rumah untuk golongan kasta Kesatria. Tampak berbeda ketika aku turun di depan rumah. Di beberapa sudut halaman, telah terpasang tenda sebagai tempat perlengkapan untuk menghidangkan makanan dan minuman kecil.

Aku melangkah masuk ke halaman rumah dengan kaki yang begitu berat. Di halaman ini, biasanya Niang menyiram tanaman yang ada di halaman rumah, memintaku menemaninya membersihkan beberapa daun kering yang berjatuhan sambil mengobrol. (hlm. 18)

Keluarga Indira berkasta Kesatria yang berperan penting pada masyakarat, karena Aji merupakan tokoh masyarakat setempat. Adapun rumah berkasta Kesatria yang dimiliki keluarga Indira disebut puri. Rumah berjenis puri memiliki halaman yang 
cukup luas karena sering digunakan untuk keperluan upacara atau kegiatan masyarakat lainnya. Oleh sebab itu, saat Indira baru saja tiba di rumahnya, dia tampak terkejut karena halaman luar puri sudah ditata dengan tenda untuk menjamu tamu yang hadir saat melayat. Saat memasuki halaman rumah, pemertahanan nilai budaya yang terwujud ialah nilai budaya yang dipegang teguh dalam hubungan manusia dengan makhluk lain berupa tanaman. Saat Niang masih hidup, ia kerap merawat dengan menyiram tanaman di halaman rumahnya. Niang pun sering meminta Indira ikut membantu Niang. Hal tersebut yang menciptakan momen kebersamaan antara Indira dan Niang. Momen tersebut yang membuat Indira merindukan Niang.

Perubahan nilai budaya juga terdapat pada peralatan kehidupan manusia dari segi tempat tinggal, pakaian adat, teknologi, dan transportasi. Perubahan nilai budaya cenderung terjadi akibat tercampurnya budaya luar terhadap budaya asli Bali. Perubahan yang terjadi cenderung lebih sedikit dibandingkan dengan pemertahanan nilai budaya. Pakaian adat pengantin yang terdapat dalam novel juga sedikit mengalami perubahan nilai budaya modern. Hal ini ditandai dengan terjadinya modifikasi yang terdapat pada kebaya pada pakaian pengantin wanita. Tidak hanya itu, pada pakaian pernikahan pria juga terdapat sedikit perubahan pakaian yang dikombinasikan dengan busana modern, yaitu jas.

Ibu memang terlihat begitu anggun hari ini dengan mengenakan busana kebaya dari bahan bordir berwarna hijau pupus. Dengan gaya modifikasi dipadu dengan gayatile berwarna kulit, bahan itu menghasilkan sebuah kebaya modern. (hlm. 263)

Laki-laki itu mengenakan busana Baliberupa Jas berwarna biru tua dipadu dengan kain songket berwarna biru tua dan kain saput songket berwarna putih gading. Juga dengan udeng songket yang berwarna senada dengan kain saputnya di atas kepala. (hlm. 265)

Max tampak begitu gagah mengenakan kemeja koko berwarna putih bersih, kain kamen batik tulis yang dilapisi saput berwarna kuning kunyit, dan sebuah udeng batik yang begitu pas di atas dahinya. (hlm. 136)

Perubahan yang terdapat pada pakaian pernikahan wanita, terwujud pada busana kebaya yang dimodifikasi dengan gaya tile berwarna kulit sehingga kebaya tersebut menjadi kebaya Bali yang bermodel modern. Walaupun hanya sedikit terjadi modifikasi kebaya, tetap tidak mengurangi makna serta kesakralan yang terdapat pada kebaya tersebut. Busana pria juga dimodifikasi dengan tren modern, yaitu ditambahkan berupa jas yang dipadupadankan dengan kain songket dan udeng yang menjadi ciri khas pakaian pernikahan pria Bali. Sedikit perubahan tersebut terjadi karena menyesuaikan dengan tren pakaian yang sedang berkembang saat ini atau kekinian.

\section{Mata Pencaharian}

Dalam novel Di Bawah Langit yang Sama karangan Helga Rif terdapat transformasi nilai budaya pada segi mata pencaharian. Hal tersebut terwujud baik dari segi pemertahanan ataupun perubahan nilai budaya. Mata pencaharian industri keluarga berupa kerajinan merupakan mata pencaharian terbesar yang masih digeluti oleh masyarakat Bali selain bidang pertanian. Kerajinan adalah segala kegiatan dalam 
perindustrian yang dikerjakan sebagian atau seluruhnya dengan tangan pembuatnya. Bidang kerajinan tangan merupakan mata pencaharian yang banyak mendapat sorotan karena berkaitan dengan kepariwisataan yang menjadi daya tarik Bali sebagai pusat pariwisata. Industri kerajinan umumnya menghasilkan barang-barang suvenir karena lapangan industri ini penting bagi penduduk sebagai sumber penghasilan vital bagi sumber devisa. Tidak jarang industri kerajinan Bali menghasilkan barang-barang yang dapat dipasarkan ke luar kota atau bahkan ke luar negeri sekalipun.
Aku menikmati perjalanan menuju desa tersebut dengan tenang, melewati Desa Tegalalang sebagai pusat kerajinan kayu. Di sepanjang jalan di desa tersebut pada penduduknya menjajakan atau menjual hasil karya kerajinan mereka yang beraneka ragam.
Sudah lama aku tidak melewati Desa Tegalalang ini. Beberapa kali, aku melihat hasil kerajinan yang pernah aku lihat dijual di Singapura. Ternyata, desa ini mampu menghasilkan kerajinan yang diekspor ke luar negeri. (hlm. 187-188)

Terdapat sebuah desa bernama Tegalalang yang masyarakatnya melakukan pemertahanan nilai budaya dari segi mata pencaharian industri keluarga kerajinan. Desa tersebut terkenal di Bali sebagai pusat kerajinan kayu. Sebagai kota wisata, Bali banyak dikunjungi oleh wisatawan baik wisatawan domestik maupun wisatawan mancanegara. Desa Tegalalang menyajikan oleh-oleh atau buah tangan berupa kerajinan tangan berbahan kayu yang khas untuk dijual kepada wisatawan yang datang mencari cendera mata. Kerajinan yang dihasilkan masyarakat Desa Tegalalang tidak hanya dijual di dalam kota, tetapi juga diekspor ke luar negeri, seperti Singapura. Hal tersebut diakui oleh Indira saat dia berada di Singapura, dia menyatakan bahwa pernah melihat hasil kerajinan hasil produksi masyarakat Desa Tegalalang.

Dalam novel Di Bawah Langit yang Sama karangan Helga Rif ditemukan perubahan nilai budaya dari segi mata pencaharian. Perubahan tersebut dirasakan saat seseorang bermata pencaharian di luar bidang yang biasa dilakukan masyarakat Bali. Perubahan tersebut terjadi akibat mengikuti perkembangan zaman atau sesuai dengan kebutuhan saat ini. Hal ini terjadi pada tokoh Indira yang memiliki mata pencaharian sebagai seorang desainer fashion di perusahaan teksil Singapura. Ia bekerja di bidang fashion yang sejajar dengan pendidikan yang ia tempuh selama sekolah fashion di Singapura.

Dan, di sinilah aku berada. Sudah dua tahun yang lalu aku lulus dari sekolah desain, dan kini aku bekerja di dunia fashion. Mempraktikkan ilmu yang telah aku dapatkan sambil belajar dengan baik, apa yang harus aku pahami di dunia fashion, untuk sebuah lini desain atas namaku sendiri kelak. Impianku. (hlm. 2)

\footnotetext{
"Gung Dira kerja di bagian desainnya. Kerjaan Gung Dira selama ini mengusulkan berbagai macam desain atau corak dan warna untuk kain yang nantinya akan diproduksi perusahaan. Usulan-usulan yang disetujui tersebut masih harus diproses melalui komputer agar warna dan garis-garisnya tepat. (hlm. 24)
}

Diketahui bahwa terjadi perubahan nilai budaya dari segi mata pencaharian pada tokoh Indira. Dia tidak bermata pencaharian di bidang pertanian, perkebunan, ataupun industri kerajinan tangan yang berkembang di daerah Bali. Indira bermata pencaharian di bidang industri tekstil internasional sebagai seorang desainer fashion. Ia bekerja 
sesuai dengan latar pendidikan yang dimilikinya pascalulus sekolah desain di Singapura. Sebagai anak yang berasal dari keluarga berkasta Kesatria, Indira memiliki pola pikir yang sangat terbuka terhadap dunia pendidikan. Ia berpandangan bahwa pendidikan merupakan salah satu aspek terpenting dalam hidupnya guna meraih dan mencapai karir yang lebih baik di masa yang akan datang.

\section{Sistem Kemasyarakatan}

Pemertahanan nilai budaya juga terwujud pada segi perjodohan dan pernikahan. Pernikahan merupakan proses yang sangat penting dalam hidup masyarakat Bali karena status pernikahan akan berpengaruh terhadap status dan pengakuan dari masyarakat. Secara umum, sistem pernikahan di Bali terdiri atas ada dua jenis adat pernikahan atau perkawinan yang dilaksanakan oleh masyarakat Bali. Pernikahan yang mengikuti berdasarkan garis keluarga pria atau biasa disebut dengan patrilineal. Pada pernikahan yang mengikuti garis patrilineal terdapat tiga cara dalam melaksanakannya. Tiga cara tersebut meliputi meminang atau mamadik atau disebut ngidih. Cara yang kedua yaitu menikah berdasarkan perjodohan kedua belah pihak keluarga yang dilakukan tanpa sepengetahuan bakal calon mempelai. Cara yang ketiga adalah kawin lari. Pernikahan kawin lari biasanya terjadi karena adanya perbedaan kasta atau wangsa pada belah pasangan ataupun terdapat permasalahan lainnya.

Selanjutnya, sistem pernikahan kedua dengan mengikuti garis keturunan dari pihak wanita atau biasa disebut dengan matrilineal. Sistem pernikahan atau perkawinan yang kedua dikenal dengan istilah Nyentanam atau Nyeburin. Prosesi pernikahan tersebut dilaksanakan oleh pihak dari keluarga wanita. Pihak pria harus mengikuti segala urusan pernikahan yang telah ditentukan pihak wanita. Pihak pria tidak terlalu mengambil andil secara besar. Namun, sebagian besar masyarakat Bali menganut garis keturunan patrilineal.

"Ya, kalau dia nggak pernah pulang, bagaimana dia bisa kenal sama perempuan Bali? Kalau nggak begitu, bisa-bisa nanti dia mencari istri yang bukan orang Bali," lanjut Tante Rani. (hlm. 54)

Benar apa yang Gung Wah katakan. Garis patrilineal yang dianut masyarakat Bali memang mengharuskan agar pihak lelaki yang meneruskan garis keturunan keluarga, termasuk mengurus merajan. (hlm. 61)

Perjodohan di Bali masih sering terjadi. Hal tersebut terwujud saat tokoh Tante Rani secara tidak langsung atau secara pragmatik menyuruh anaknya, Gung Wah, agar dia mencari jodoh dan menikah hanya dengan wanita Bali. Oleh sebab itu, Tante Rani selalu menyuruh anaknya agar selalu kembali ke kampung halamannya di Bali agar tetap mendapatkan wanita Bali. Hal tersebut membuat Indira tidak setuju, sebab, menurutnya perjodohan yang dilakukan orang tua terhadap anaknya sudah tidak sesuai dengan perkembangan zaman saat ini. Setiap individu berhak menentukan pasangan hidupnya masing-masing.

Dalam novel Di Bawah Langit yang Sama karangan Helga Rif ditemukan perubahan nilai budaya pada sistem kemasyarakatan. Perubahan terdapat pada segi ekonomi di sistem kasta, perjodohan, dan pernikahan. Perubahan nilai budaya dapat terjadi pada individu tokoh atau yang terjadi pada masyarakat setempat. Perubahan nilai budaya terjadi pada sistem kasta di Bali disebabkan oleh segi ekonomi. Pada masa kini, 
Brahmana sebagai kasta tertinggi tidak selalu mendominasi pada perekonomian di Bali, begitu pun sebaliknya.

\begin{abstract}
"Tingkatan kasta itu masih kami pegang teguh," ucapku menutup pelajaran singkat tentang tingkatan masyarakat Bali kepada Max.

"Tapi, aku tidak melihat perbedaan kasta itu di kehidupan sehari-hari masyarakat Bali," komentar Max setelah mendengar penjelasanku yang panjang lebar mengenai tingkatan kasta di Bali.

"Itu karena telah terjadi perubahan ekonomi. Tidak semua kasta tinggi memiliki kekayaan yang besar lagi. Bisa jadi terjadi sebaliknya, kasta rendah kini menjadi orang penting,"jelasku. (hlm. 154)
\end{abstract}

Berdasarkan kutipan di atas, Indira memberikan penjelasan mengenai sistem kasta pada Max. Pada zaman ini, tingkatan kasta di keluarga Bali masih dipegang teguh oleh masyarakatnya. Akan tetapi, terjadi perubahan nilai budaya pada segi ekonomi di tingkatan kasta pada masyarakat, bahwa saat ini perbedaan tingkatan kasta tersebut sebagian besar tidak dapat terlihat secara jelas dalam kehidupan sehari-hari. Hal tersebut terjadi karena telah terjadi perubahan dari segi ekonomi. Saat ini, tidak semua kasta tinggi, seperti Brahmana, Kesatria memiliki kekayaan atau ekonomi yang tinggi. Bisa jadi kasta-kasta bahwa Waisya, Sudra yang memiliki perekonomian yang tinggi serta memiliki jabatan yang penting. Oleh sebab itu, ekonomi saat ini tidak menjadi tolak ukur utama lagi pada sistem kasta di Bali pada kehidupan sehari-hari. Untuk mengetahui sistem kasta suatu keluarga perlu diselidiki dan cari tahu secara mendalam. Namun, hal tersebut tidak terjadi pada keseluruhan masyarakat. Hanya terjadi pada sebagian masyarakat yang memiliki perjuangan hidup yang tinggi saja.

\title{
Sistem Bahasa
}

Seperti halnya sistem bahasa yang terdapat dalam novel Di Bawah Langit yang Sama karangan Helga Rif sangat beraneka ragam. Namun, sistem bahasa yang dominan muncul ialah sistem bahasa daerah Bali. Oleh sebab itu, dalam novel tersebut terdapat pemertahanan nilai budaya pada sistem bahasa.

Dengan segera, aku menjawab panggilannya. “Om Swastiastu, Gung Is,” salamku kepada adikku, Anak Agung Ayu Iswari. Gung Is biasa kami memanggilnya.

"Om Swastiastu, Mbok Gung. Lagi sibuk?" balasnya Iswari biasa memanggilku Mbok Gung, sedangkan orang lain biasa memanggilku dengan Gung Indira. Gelar Anak Agung yang kumiliki tentu saja tidak berlaku di Singapura. (hlm. 12)

Terdapat terwujud pemertahanan. Hal tersebut dikarenakan Indira tetap menerapkan nilai budaya saat dia berada di Singapura dengan melakukan komunikasi melalui telepon genggam dengan bahasa Bali yang dilakukan terhadap adiknya di Bali. Sistem bahasa yang terwujud ialah berupa alih kode yang dilakukan Indira saat mengucapkan salam pembuka kepada adiknya dengan menggunakan bahasa Bali. Selain itu, Indira menyebut adiknya dengan istilah Gung. Gung merupakan gelar nama Anak Agung atau istilah yang digunakan dan berlaku pada sistem kasta Kesatria yang lekat pada keluarga Indira.

Selain terdapat pemertahanan nilai budaya, novel Di Bawah Langit yang Sama karangan Helga Rif juga ditemukan perubahan nilai budaya pada sistem bahasa. 
Perubahan tersebut dilakukan guna menyesuaikan dengan situasi dan kondisi saat berkomunikasi. Hal tersebut guna menciptakan keselarasan saat berkomunikasi jika menggunakan bahasa yang berbeda dan pesan yang ingin disampaikan tersampaikan dengan baik dan benar.

“Yes, I'm going today. Why?”jawabku akhirnya. (hlm. 4)

"Miss you, Max. Apa kabar London?" tanyaku. Max baru kembali dari perjalanan bisnisnya ke London kemarin. Aku tahu, dia pasti masih lelah hari ini, tetapi setumpuk pekerjaan telah menunggunya saat ini. (hlm. 6-7)

Terjadi perubahan nilai budaya dari segi sistem bahasa. Indira melakukan campur kode antara bahasa Inggris dan bahasa Indonesia saat berkomunikasi dengan kekasihnya, Max. Indira sering melakukan perubahan bahasa dari bahasa Indonesia ke bahasa Inggris saat berkomunikasi dengan Max. Adapun kemampuan bahasa yang dimiliki Indira ialah bahasa ibu yang dimiliki yaitu bahasa Bali, lalu bahasa pertamanya adalah bahasa Indonesia, dan bahasa keduanya adalah bahasa Inggris. Perubahan nilai budaya saat Indira di Singapura perlu dilakukan agar proses komunikasi berjalan dengan lancar. Selain dengan Max, Indira pun melakukan perubahan bahasa saat berkomunikasi dengan rekan kerjanya di kantor. Hal tersebut dikarenakan tempat Indira bekerja sebagian besar orangnya menggunakan bahasa Inggris dan sedikit yang menggunakan bahasa Indonesia ataupun bahasa Melayu.

\title{
Kesenian
}

Pemertahanan nilai budaya juga terdapat pada seni musik, khususnya pada lagulagu keagamaan berupa kidung mantra. Saat berada di Singapura, Indira acap kali mendengarkan kidung suci atau lagu-lagu gamelan Bali. Hal tersebut salah satu cara Indira untuk mengobati kerinduannya terhadap rumah di Bali. Dengan mendengarkan kidung suci, membuat Indira merasa tenang dan seakan-akan membawa dirinya pada suasana kehidupan di Bali yang asri, damai, dan sejuk.

\begin{abstract}
Aku memejamkan mata, mendengarkan kidung suci yang terdengar dari stereo yang dipasang seseorang di bale gede untuk keperluan upacara ini. Terkadang, kala aku rindu rumah, aku menghidupkan lagu-lagu kidung mantra atau lagu-lagu gamelan Bali di apartemen. (hlm. 21)
\end{abstract}

\begin{abstract}
Niang yang biasanya selalu menyanyikan kidung Bali saat kami akan melakukan persembahyangan di berbagai tempat seperti halnya di pura juga. Suara Niang selalu terdengar begitu merdu, jernih, dan membawa ketenangan hati sehingga kami akan larut dalam suasana damai di dalam Pura. (hlm. 74)
\end{abstract}

Wujud pemertahanan nilai budaya terdapat pada kesenian lagu, yaitu pada kidung mantra atau lagu-lagu gamelan Bali. Kidung suci merupakan nyanyian doa atau seni musik yang dimiliki oleh kaum Hindu di Bali yang diperdengarkan untuk keperluan upacara adat keagamaan. Seperti halnya, kidung suci yang tetap dipilih dan diperdengarkan untuk keperluan upacara Ngaben tanpa menggantinya dengan lagu lain. Lagu kidung merupakan bacaan kita umat Hindu yang kemudian dilantunkan dengan nada-nada yang diiringi dengan musik tradisional Bali. Selain itu, kidung suci atau lagulagu gamelan Bali hanya dimiliki oleh daerah Bali. Setiap daerah di Indonesia memiliki 
lagu-lagu gamelan atau lagu daerah yang berbeda.

Dalam novel Di Bawah Langit yang Sama karangan Helga Rif tidak ditemukan perubahan nilai budaya dari segi kesenian, baik dari segi musik, seni suara, seni tari, seni drama, dan sebagainya. Oleh karena itu, yang ditemukan hanyalah pemertahanan nilai budaya.

\section{Sistem Pengetahuan}

Pemertahanan nilai budaya terwujud pada sistem pengetahuan berupa pendidikan strata 1 yang ditempuh oleh Indira. Dia mempertahankan untuk menempuh pendidikan formal hingga strata 1 dengan universitas yang berada di Bali. Indira tidak mencari universitas yang yang berada di luar Bali. Walau demikian, universitas di Denpasar pun cukup memadai. Namun, sangat disayangkan Indira tidak menyebutkan secara pasti nama tempat universitas tersebut. Mengingat terdapat beberapa universitas yang berada di wilayah Denpasar, Bali.

\section{Awalnya, orangtuaku keberatan akan niatku melanjutkan sekolah yang tidak} ada hubungannya dengan predikat Sarjana Ekonomi yang telah kuraih. (hlm. 2)

Ketika aku harus kuliah di Denpasar beberapa tahun yang lalu, aku lebih memilih untuk pulang pergi Ubud-Denpasar yang memakan waktu satu jam perjalanan daripada harus menetap di Denpasar. (hlm. 17)

Dapat dilihat bahwa Indira sebagai anak dari keluarga berkasta Kesatria memiliki kesempatan untuk tetap melanjutkan pendidikan hingga perguruan tinggi. Oleh sebab itu, dia melanjutkan pendidikan saat strata 1 di Denpasar dengan jurusan ekonomi. Setelah ia menyelesaikan pendidikan S-1 dengan predikat Sarjana Ekonomi, Indira ingin melanjutkan sekolah kembali. Namun, saat itu berbeda jurusan yaitu sekolah desain. Hal tersebut sempat mendapat reaksi penolakan dari orang tuanya. Pasalnya, orang tua Indira menganggap bahwa sekolah desain yang akan diambil Indira sama sekali tidak ada hubungannya dengan Sarjana Ekonomi. Akan tetapi, Indira meyakinkan dan menjelaskan kepada orang tuanya sehingga disetujui untuk melanjutkan sekolah desain.

Perubahan nilai budaya sistem pengetahuan terjadi pada kemampuan berbahasa dan perubahan pola pikir tentang kesadaran pendidikan formal. Perubahan pada sistem pengetahuan berbahasa terjadi pada tokoh Max. Sebagai pria berkebangsaan Singapura, Max tidak hanya memiliki pengetahuan tentang berbahasa Inggris, tetapi juga mempelajari tentang bahasa Melayu dan Indonesia.

Dia pasti penasaran dengan apa yang aku bicarakan. Walau Max mengenal sedikit bahasa Melayu, aku yakin dia tidak memahami dengan baik bahasa Indonesia yang aku gunakan. (hlm. 13)

Max mengalami perubahan pada sistem pengetahuannya. Sebagai pria berkebangsaan Singapura, pada mulanya dia hanya memiliki pengetahuan tentang bahasa Inggris yang digunakan dalam kehidupan sehari-hari. Namun, Singapura tak lepas dari sejarahnya yang merupakan bagian dari Malaysia. Oleh sebab itu, sebagian besar orang Singapura masih memahami dan sedikit menggunakan bahasa Melayu walau tak sepenuhnya menggunakan bahasa Melayu dalam kehidupan sehari-hari. Hal 
tersebut juga dialami oleh tokoh Max yang memiliki setidaknya pengetahuan bahasa Melayu dan memahaminya.

\section{Sistem Religi}

Pemertahanan nilai budaya pada sistem religi yang mencakup tentang keyakinan atau peribadatan yang dialami pada tokoh Indira. Sebagai orang yang beragama Hindu, Indira melakukan pemertahanan nilai budaya saat berada di Singapura dengan cara selalu melakukan ritual persembahyangan setiap pagi setelah bangun tidur. Persembahyangan yang dilakukan oleh tokoh Indira untuk memohon keselamatan kepada Tuhan bagi dirinya dan orang-orang yang disayanginya.

Setelah menghidupkan tiga buah dupa, aku memulai ritual persembahyangan yang kulakukan setiap pagi.Duduk bersimpuh di depan sebuah pelangkiran yang kupasang di dinding. Aku mulai berdoa kepada Tuhan, memohon keselamatan diriku dan semua orang yang aku sayangi. (hlm. 5)

Aku hanya duduk bersimpuh di bawah lantai yang beralaskan semen, tanpa alas apa pun yang aku siapkan untuk diriku sendiri. Menyalakan beberapa dupa untuk aku sematkan di beberapapelinggih (tempat sembahyang) yang ada di merajan dan mulai melakukan meditasi. (hlm. 223)

Uraian di atas memperlihatkan bahwa Indira melakukan pemertahanan nilai budaya pada sistem religi melalui kebiasaannya setiap pagi, yaitu selalu melakukan ritual pesembahyangan di apartemennya. Indira biasa melakukan persembahyangan tersebut sebelum berangkat ke kantor. Persembahyangan yang dilakukan Indira mengacu berdasarkan agama Hindu. Persembahyangan adalah suatu bentuk kegiatan keagamaan yang dilakukan hamba guna menciptakan komunikasi dengan Tuhan, dewa, roh, atau kekuatan yang bersifat gaib yang dipuja dengan melakukan kegiatan atau halhal yang disengaja.

Perubahan nilai budaya pada sistem religi terjadi pada perubahan yang terjadi pada sebagian umat Hindu yang tidak mengonsumsi daging sapi. Umat Hindu tidak memakan daging sapi sebab dianggap hewan yang suci di agama Hindu. Seperti halnya umat muslim yang tidak memakan daging babi karena haram. Namun, di era modern saat ini sebagian besar umat Hindu telah berubah pandangan bahwa mengonsumsi daging sapi tidak bermasalah. Hal tersebut seperti yang dialami oleh Indira. Ia mengonsumsi daging sapi, tetapi tetap menganggap sapi sebagai hewan suci dalam agamanya.

Di dalam pelajaran agama Hindu, sapi adalah salah satu tunggangan yang digunakan oleh salah satu dewa kami. Jadi, umat Hindu menganggap bahwa sapi adalah makhluk suci yang harus dihormati keberadaannya. Kebanyakan dari kami, umat Hindu di dunia memang tidak mengonsumsi sapi, tapi aku makan, kok," jelasku lebih lanjut. (hlm. 38)

Berdasarkan uraian tersebut, terlihat jelas bahwa dalam agama Hindu, sapi merupakan hewan yang dianggap sebagai makhluk suci. Hal tersebut dikarenakan sapi merupakan salah salah satu tunggangan dewa dalam agama Hindu. Oleh sebab itu, umat Hindu sangar menghormati sapi, salah satu caranya adalah dengan tidak mengonsumsi 
dagingnya. Namun, hal tersebut berbeda dengan Indira. Indira merupakan golongan umat Hindu yang tetap mengonsumsi daging sapi tetapi tetap menghormati sapi sebagai kendaraan dewa mereka.

\section{KESIMPULAN}

Berdasarkan hasil deskripsi di atas terlihat adanya transformasi nilai budaya dalam novel Di Bawah Langit yang Sama karangan Helga Rif. Transformasi tersebut terjadi baik dari segi pemertahanan maupun perubahan nilai budaya. Jumlah keseluruhan tabel analisis yang mengandung unsur transformasi nilai budaya sebanyak 103 data. Adapun pemertahanan nilai budaya terwujud sebanyak 75 data, sedangkan perubahan nilai budaya 28 data.

Pemertahanan nilai budaya yang terwujud pada tujuh unsur budaya, yaitu (1) peralatan kehidupan manusia, (2) mata pencaharian, (3) sistem kemasyarakatan, (4) sistem bahasa, (5) kesenian, (6) sistem pengetahuan, dan (7) sistem religi. Pemertahanan nilai budaya unsur yang paling banyak terdapat dalam novel ialah pada unsur peralatan kehidupan manusia dan sistem kemasyarakatan. Dalam unsur peralatan kehidupan manusia, pemertahanan terwujud pada pakaian adat Bali. Pemertahanan yang dilakukan tokoh dalam novel maupun masyarakat Bali sangat mempertahankan pakaian-pakaian adat Bali yang memiliki ciri khas tersendiri. Hal tersebut banyak ditemukan saat proses upacara-upacara adat, seperti saat upacara Ngaben dengan serangkaian kegiatannya dan upacara pernikahan. Selain itu, pakaian adat juga tetap dipertahankan oleh masyarakat Bali saat melaksanakan kehidupan sehari-hari.

Sementara itu, perubahan nilai budaya juga terdapat dalam novel Di Bawah Langit yang Sama. Namun, tidak terwujud dalam semua tujuh unsur budaya hanya terdapat enam unsur saja yang meliputi (1) peralatan kehidupan manusia, (2) mata pencaharian, (3) sistem kemasyarakatan, (4) sistem bahasa, (6) sistem pengetahuan, dan (7) sistem religi. Sementara itu, pada unsur (5) kesenian tidak ditemukan perubahan nilai budaya. Perubahan nilai budaya paling banyak terjadi pada peralatan kehidupan manusia dan sistem kemasyarakatan. Perubahan nilai budaya yang terjadi pada peralatan kehidupan manusia akibat perkembangan zaman yang kian modern.

\section{UCAPAN TERIMA KASIH}

Terima kasih kepada seluruh pihak yang berkenan diajak diskusi dan mendukung penelitian serta penulisan artikel ilmiah ini sehingga dapat dipublikasikan dan memberikan manfaat.

\section{REFERENSI}

Amalia, A. (2018). Kepribadian tokoh tritagonis dalam novel Tentang Кати karangan Tere Liye perspektif psikologi sastra serta implikasinya terhadap pembelajaran sastra di SMA. Jurnal AKSIS: Jurnal Pendidikan Bahasa dan Sastra Indonesia, 2(2), 154-164. doi: https://doi.org/10.21009/AKSIS.020202

Endraswara, S. (2008). Metodologi Penelitian Sastra: Epistemologi, Model, dan Teori. Yogyakarta: Media Pressindo.

Endraswara, S. (2013). Metodologi Penelitian Antropologi Sastra. Yogyakarta: Ombak.. 
Koentjaraningrat. (2015). Pengantar Ilmu Antropologi. Jakarta: Rineka Cipta.

Maran, R. R. (2000). Manusia dan Kebudayaan dalam Perspektif Ilmu Budaya Dasar. Jakarta: Rineka Cipta.

Mardimin, J. (1994). Jangan Tangisi Tradisi Transformasi Budaya Menuju Masyarakat Indonesia Modern. Yogyakarta: Kanisius.

Praptiwi, F.N. (2017). Pendidikan karakter tokoh utama novel Cahaya Cinta Pesantren karangan Ira Madan dan Semester Pertama di Malory Towers karangan Enid Blyton. Jurnal AKSIS: Jurnal Pendidikan Bahasa dan Sastra Indonesia, 1(2), 234-252. doi: https://doi.org/10.21009/AKSIS.010206

Pujileksono, S. (2016). Pengantar Antropologi Memahami Realitas Sosial Budaya Edisi Revisi. Malang: Intrans Publishing.

Purwahida, R. (2017). Interaksi sosial pada kumpulan cerpen Potongan Cerita di Kartu Pos karangan Agus Noor dan implikasinya terhadap pembelajaran sastra di SMA. Aksis: Jurnal Pendidikan Bahasa dan Sastra Indonesia 1(1). 118-134. doi: doi.org/10.21009/AKSIS.010107

Purwahida, R. (2018). Problematika Pengembangan Modul Pembelajaran Baca Tulis Anak Usia Sekolah Dasar. Aksis: Jurnal Pendidikan Bahasa dan Sastra Indonesia 2(1). 118-134. doi: doi.org/10.21009/AKSIS.020108

Ratna, N. K. (2011). Antropologi Sastra: Peranan Unsur-unsur Kebudayaan dalam Proses Kreatif. Yogyakarta: Pustaka Pelajar.

Rif, H. (2015). Di Bawah Langit yang Sama. Jakarta: Gagas Media.

Sudibyo, L., Sudargono, A., Sudiatmi, T., \& Triyanto, B. (2013). Ilmu Sosial Budaya Dasar. Yogyakarta: ANDI.

Suhita, S., \& Purwahida, R. (2018). Apresiasi Sastra Indonesia dan Pembelajarannya. Bandung: Remaja Rosdakarya.

Sumardjo, J., \& Saini K.M. (1994). Apresiasi Kesusastraan. Jakarta: Gramedia.

Warsiman. (2018). Pengantar Pembelajaran Sastra: Sajian dan Kajian Hasil Riset. Malang: UB Press.

Wellek, R., \& Austin W. (2014). Teori Kesusastraan. (Terjemahan: Theory of Literature). Jakarta: Gramedia Pustaka Utama. 